\title{
Effect of Growth Strategies on the Performance of Food Manufacturing Firms in Nairobi County, Kenya.
}

\author{
Norah Muchele* Henry Kombo \\ Faculty of Commerce, Egerton University, Kenya P.O. Box 536- 0107 Njoro, Kenya
}

\begin{abstract}
To increase performance, manufacturing firms in Kenya formulate and implement growth strategies. However, past studies in Kenya have not examined the effect of growth strategies on the performance of food manufacturing firms. The objective of this study was to determine the effect of growth strategies on the performance of food manufacturing firms in Nairobi County, Kenya. A proportionate sample of 71 firms representing seven sub-sectors of food manufacturing firms in Nairobi County was used. Primary data was collected from 64 firms using structured questionnaire administered to the Managers of the firms. The results revealed positive effect of growth strategies on organizational performance. The paper concluded that firms implementing growth strategies achieve higher organizational performance.
\end{abstract}

Keywords: Growth Strategies, Market Penetration, Market Development, Product Development, Diversification and Organizational Performance

DOI: $10.7176 / \mathrm{EJBM} / 11-15-06$

Publication date:May $31^{\text {st }} 2019$

\section{Introduction}

Organizations operate within an environment which is constantly changing and increasingly competitive. These developments are affecting the performance of food manufacturing firms in Kenya (Government of Kenya, 2017). To improve performance in the increasingly competitive environment, firms are adopting various strategies including growth strategies which are believed to fit the firms to their environment and improve the firms' performance (Aosa,1992).

Guided by the Strategic Management Model (Porter, 1985), it is postulated in this study that growth strategies are vital in enhancing efficiency and effectiveness that translates to increased firm performance. Therefore, it is expected that food manufacturing firms implement growth strategies to enhance performance.

Past research in the field of strategy suggests that growth strategies practiced by a firm is critical in improving the firm's performance (Odiwor,2014). Despite the suggested linkage between growth strategies and organizational performance, past empirical studies have not focused on effect of growth strategies on organizational performance. Thus, the objective of this study was to determine the effect of growth strategies on the performance of food manufacturing firms in Nairobi County, Kenya.

The rest of the paper is organized as follows: The second section reviews related literature and the research hypotheses. The third section presents the research methodology which describes the population, sample, data collection, measurement of variables and data analysis techniques. The fourth section discusses the results. The fifth section presents conclusions and finally, the sixth section presents the recommendations of the study.

\section{Growth Strategies and Organizational Performance}

Growth strategies refer to the methods that a firm uses in order to achieve its goals for expansion (Ansoff, 1957). These growth strategies have been playing the central role in the expansion of firms and have enabled them to increase their market shares and develop new markets and products. The different types of growth strategies include joint venture, horizontal and vertical integration, mergers and acquisitions (Mital, Robinson Jr \& Pearce II, 2008) and finally the Ansoff Matrix strategies which include market penetration, market development, product development and diversification. The study adopted the Ansoff Matrix (1957) which classifies and explains different growth strategies for a firm. It is used by firms that have growth targets or a strategy of specialization. This model allows for a cross analysis of the products and markets of a firm and facilitates decision making. The strategies in Ansoff's matrix include market penetration, product development, market development and diversification.

Market penetration occurs where the firm is trying to expand its sales in the existing market. Existing products are sold to current customers. The product is not modified but the firm is seeking to increase its revenues by means of promoting or repositioning its products. The firm has to convince potential clients and divert competitors. This strategy is used by firms in order to increase sales without drifting from the original product-market strategy. A study conducted by Day (2004) concluded that firms often penetrate markets by improving the product quality or level of service or attracting nonusers of the products or convincing current customers to use more of the firm's product and consequently increase performance of the firm.

In market development, the firm tries to increase its sales by introducing its current products on new markets. 
A range of existing products is introduced in new markets. Again, the product is not modified it is just sold to a new target. By taking into consideration cultural differences, the products may undergo minor changes. The move could be aimed at maintaining or increasing the market share of current products and this can be achieved through a combination of competitive pricing strategies, advertising, sales promotion, and perhaps more resources dedicated to personal selling (Eisenhardt \& Schoonhoven, 2010). A study conducted by (Kotler \& Armstrong, 2011) argued that by adopting market development strategies, the management is attempting to sell greater volumes of existing products in new markets, this may involve increasing revenue which is most likely to lead to high rates of growth.

For product development, the firm is trying to increase its sales by introducing new or modified products in the market. The new products are sold to the customers through existing distribution channels. The ultimate motivation behind product development is for the companies to protect their overall market share (Ittner \& Larcker, 2011). In pursuing a strategy based on product development, management is attempting to sell a new product to existing customers (Lee \& Grewal, 2004). Efforts are focused on the development and innovation of new product offerings with which to replace existing ones. New products are then marketed to existing customers (Miller, 1987; Porter, 1985). A study by Rono (2015) examined the effect of growth strategies on the competitiveness of firms in Kenyan cement industry and concluded that firms were sourcing and using product development strategies as a basis of improving effectiveness and efficiency, and hence improved performance.

Diversification is a product-market growth strategy in which a new product is developed to serve a completely new market (Ansoff, 1957). An established brand develops a new product that serves a different market than what it was serving before. These radical innovations require a lot of research and development. The risks of diversification can be minimized by moving into related markets (Nath, Nachiappan \& Ramanathan, 2010). A study conducted by Anyango (2007) on the challenges of strategy implementation found that diversification, if carefully implemented, increases the firm's sales and market share which in turn results into higher performance.

A study by Arkolakis (2008) demonstrated that market penetration is one of the most important growth strategies employed by a few organizations. It is therefore expected that firms that practice market penetration achieve higher performance. Njuguna (2008) concluded that market development if well implemented could lead to an improved performance in SMEs. A study conducted by Johnson, Whittington and Scholes (2009) demonstrated that the configuration of activities used by companies to acquire new products is an important influencing factor of organizational performance and that developing new products is another strategic option for an organization. It is therefore expected that firms that practice product development achieve higher performance. A study conducted by Anyango (2007) found that diversification, if carefully implemented, increases the firm's sales and market share which in turn results into higher performance.

In view of the theoretical arguments and prior empirical evidence, the following hypotheses were proposed: $\mathrm{HA}_{1}$ : Market penetration has a positive effect on organizational performance

$\mathrm{HA}_{2}$ : Market development has a positive effect on organizational performance.

$\mathrm{HA}_{3}$ : Product development has a positive effect on organizational performance

$\mathrm{HA}_{4}$ : Diversification has a positive effect on organizational performance.

$\mathrm{HA}_{5}$ : Market penetration, market development, product development and diversification jointly have a positive effect on organizational performance.

\section{Methodology}

\subsection{Population and Sample}

Data aggregation and analysis was done at firm level. Thus, the population of this study comprised all food manufactures firms in Nairobi Kenya. There were a total of 87 food manufacturing firms at the time of the study which were members of Kenya Association of Manufacturers (KAM, 2017). The firms are classified into 7 subsectors of food manufacturing on the basis of the food products they manufacture. The sub-sectors are: Alcoholic Beverages; Bakers and Millers; Cocoa, Chocolate and Sugar; Juices/Waters/Dairy/Carbonated Soft Drinks; Tobacco; Vegetable Oils and Slaughtering/Preparation and Preservation of Meat. Given the large size of the population, a sample was used for this study.

Considering the desired confidence level (95\% confidence level) and the margin of error (set at $5 \%$ in this study), a sample of 71 manufacturing firms was used for the study. To select the 71 firms which constituted the sample units, proportionate sampling method was used to ensure the sample was representative of the 7 sub-sectors of food manufacturing to enhance generalizability of the results.

\subsection{Data Collection}

To achieve the objectives of this study, primary data was collected. In gathering the data, questionnaire was used as the instrument for data collection. The questionnaire with closed ended Likert-type scales was developed to measure the respondents' perceptions of the existence and magnitude of growth strategies and organizational performance in their organizations. Since the unit of analysis in this study was the firm, one respondent was 
targeted in each firm. The respondents were the executive officers of the firms conversant with the organization's strategy and performance. The survey took a total of six months from June to December 2018.

\subsection{Measurement of Variables}

In this study, the independent variable was growth strategies while the dependent variable was organizational performance. Following the Ansoff matrix (Ansoff, 1957), growth strategies were conceptualized in terms of market penetration, market development, product development and diversification and was measured using a 5point Likert type scale, measuring the respondent's level of agreement with given statement on each of the independent variables; where $1=$ strongly disagree, $2=$ disagree, $3=$ neutral, $4=$ agree and $5=$ strongly agree. Organizational performance was measured using market performance or non-financial measures, this included market share and sales (Lebans and Euske, 2006)

\subsection{Data Analysis}

Descriptive statistics specifically, the mean and standard deviation were used to describe growth strategies and performance of the firms. Pearson's correlation was used to examine how the dimensions of the independent variable, growth strategies, were related with the dependent variable, organizational performance. To test the hypothesis which predicted that growth strategies have a positive effect on organizational performance, multiple regression analysis was used. Organizational performance was regressed on the dimensions of growth strategies that is, market penetration, market development, product development, diversification, and organizational performance were used in the analysis. The following multiple regression model was developed:

$\mathrm{Y}=\mathrm{a}+\beta_{1} \mathrm{X}_{1}+\beta_{2} \mathrm{X}_{2}+\beta_{3} \mathrm{X}_{3}+\beta_{4} \mathrm{X}_{4+\varepsilon}$

Where:

$\mathrm{Y}=$ is the dependent variable (Organizational Performance)

$\mathrm{a}=$ constant

$\mathrm{X}_{1}=$ Market Penetration

$\mathrm{X}_{2}=$ Market Development

$\mathrm{X}_{3}=$ Product Development

$\mathrm{X}_{4}=$ Diversification

$\beta_{1}-\beta_{4}=$ regression coefficients

$\varepsilon=$ error term

\section{Results and Discussion}

4.1 Response Rate

The study targeted a sample size of 71 respondents in collecting data; out of which 64 filled in and returned the questionnaires making a response rate of $90.1 \%$. This response rate was considered to be excellent as suggested by Mugenda and Mugenda (2003).

\subsection{Reliability and Validity}

In assessing the reliability of the research instruments, Cronbach alpha coefficient was used. The results are presented in Table 4.1 .

Table 4.1: Cronbach alpha coefficients

\begin{tabular}{lcc}
\hline \multicolumn{3}{c}{ Overall Reliability Statistics } \\
\hline \multicolumn{2}{c}{ Number of Items } & Cronbach's Alpha \\
\hline \multicolumn{2}{c}{ Cronbach alpha coefficients for the measurement scales for the constructs } \\
\hline \multicolumn{2}{c}{ Cronbach's Alpha } & Number of Items \\
\hline Scale & 0.807 & 11 \\
Market Penetration & 0.844 & 6 \\
Market Development & 0.823 & 6 \\
Product Development & 0.909 & 8 \\
Diversification & 0.796 & 5 \\
Organizational Performance & \\
\hline
\end{tabular}

As shown in Table 4.1, all the research constructs had alpha coefficients of above 0.7 . Thus, the instrument met the recommended threshold of 0.7 and this was considered reliable (Oso \& Onen, 2011). To ascertain the validity, the instrument was assessed by experts in the Faculty of Commerce, Egerton University.

\subsection{Descriptive Statistics of Study Variables}

In describing the study variables, means and standard deviation were used. The results describing market penetration strategy in the firms are presented in Table 4.2. 
Table 4.2: Mean and Standard Deviation for Measures of Market Penetration

\begin{tabular}{lrr}
\hline Market Penetration Items & N Mean & $\begin{array}{c}\text { Std. } \\
\text { Deviation }\end{array}$ \\
\hline Focuses on improving performance by reducing prices of existing products in existing64 3.86 & 1.05 \\
markets. & 644.23 & 0.50 \\
Convinces current customers to use more of the existing products. & 644.09 & 0.81 \\
Acquires a rival in the same market to increase both market share and sales. & 644.02 & 0.88 \\
Introduces loyalty schemes and incentives to increase usage by existing customers. & $\mathbf{4 . 0 5}$ & \\
Overall Mean
\end{tabular}

The mean score for the market development dimension was 4.05. These results were interpreted to mean that the firms agreed that they practice market penetration. The findings concur with the study conducted by Day (2004) who concluded that firms often penetrate markets by improving the product quality or level of service or attracting nonusers of the products or convincing current customers to use more of the firm's product and consequently increase performance of the firm.

Table 4.3: Mean and Standard Deviation for Measures of Market Development

\begin{tabular}{lrl}
\hline Market development Items & MeanStd. Deviation \\
\hline Expands into new geographical markets & 4.30 & 0.63 \\
Introduces new distribution channels & 3.95 & 0.63 \\
Differentiates pricing policies to capture new markets & 4.22 & 0.55 \\
Adopts promotional strategies to inform and persuade new consumers of existing products 3.98 & 0.75 \\
Overall Mean & $\mathbf{4 . 1 1}$ \\
\hline
\end{tabular}

The mean score for Market Development was 4.11 which reflects that the responses were not very far from each other among the respondents. The results generally indicated that the respondents agreed with the statements regarding market development in their organizations. These results were interpreted to mean that the firms agreed that they practice market development. The findings are consistent with the study conducted by Kotler \& Armstrong (2011) who stated that by adopting market development strategies, the management is attempting to sell greater volumes of existing products in new markets, this may involve increasing revenue which is most likely to lead to high rates of growth.

Table 4.4: Mean and Standard Deviation for Measures of Product Development

\begin{tabular}{lll}
\hline Product Development Items & Mean & Std. Deviation \\
\hline Develops new products to appeal to the existing market & 4.31 & 0.59 \\
Employs differentiation strategy on its products & 4.61 & 0.49 \\
Invests in innovation to develop new products & 3.61 & 1.08 \\
Modifies features of its existing products to meet the ever-changing customer needs & 4.06 & 0.73 \\
Overall Mean & $\mathbf{4 . 1 5}$ & \\
\hline
\end{tabular}

The overall mean for the items for Product Development was 4.15 which indicated that the respondents agreed with the statements regarding aspects of product development in their organizations to a great extent. The results indicated that the respondents strongly agreed with the statements regarding product development in their organizations. These results indicated that the firms agreed that they practice product development. The findings concur with a study by Rono (2015) which examined the effect of growth strategies on the competitiveness of firms in Kenyan cement industry and concluded that firms were sourcing and using product development strategies as a basis of improving effectiveness and efficiency, and hence improved performance.

Table 4.5: Mean and Standard Deviation for Measure of Diversification

\begin{tabular}{|c|c|c|}
\hline Diversification Items & Mear & $\begin{array}{l}\text { Std. } \\
\text { Deviation }\end{array}$ \\
\hline Markets new products in new markets & 3.86 & 1.05 \\
\hline $\begin{array}{l}\text { Conducts an honest assessment of risks involved in undertaking of new products in new } \\
\text { markets }\end{array}$ & 4.27 & 0.65 \\
\hline Moves to new related business & 4.00 & 0.84 \\
\hline Moves to new unrelated business & 3.83 & 0.83 \\
\hline Overall Mean & 3.99 & \\
\hline
\end{tabular}

The overall mean for the items for diversification was 3.99 which showed that the responses were not far spread from each other among the respondents thus indicating low variability in response to the statements. The results generally indicated that the respondents agreed with the statements regarding diversification in their organizations. These results were interpreted to mean that the firms agreed that they practice diversification. The findings are consistent with the study conducted by Anyango (2007) on the challenges of strategy implementation which found that diversification, if carefully implemented, increases the firm's sales and market share which in 
turn results into higher performance.

4.3.2 Organizational Performance

Table 4.6: Mean and Standard Deviation for Measures of Organizational Performance

\begin{tabular}{lll}
\hline Organizational Performance & Mean & Std. Deviation \\
\hline Market Share & 4.44 & 0.59 \\
Sales & 4.08 & 0.80 \\
Overall Mean & $\mathbf{4 . 2 6}$ & \\
\hline
\end{tabular}

As shown in Table 4.6, the mean score for market performance dimension was 4.26 which showed that the responses were not far spread from each other among the respondents thus indicating low variability in response to the statements. The item 'market share' had a higher mean score $(\mathrm{M}=4.44, \mathrm{SD}=.59)$ and the item 'sales" had a lower mean score $(\mathrm{M}=4.08, \mathrm{SD}=.80)$. This mean score indicates that the respondents generally agreed that their firm's performance increased.

\subsection{Test of Hypotheses}

The study sought to examine how the variables of the study: market penetration, market development, product development, diversification and organizational performance were related (Hypothesis HA1 to HA4). The hypotheses were tested using Pearson's correlation analysis. The results are presented in Table 4.7.

Table 4.7: Correlation Matrix for Market Penetration, Market Development, Product Development, Diversification and Organizational Performance

\begin{tabular}{|c|c|c|c|c|c|c|}
\hline & & 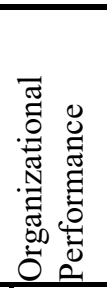 & 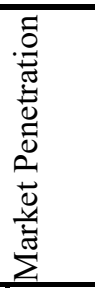 & 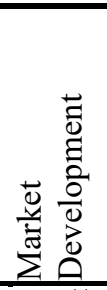 & 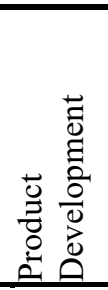 & 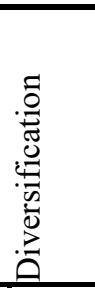 \\
\hline \multirow{3}{*}{$\begin{array}{l}\text { Organizational } \\
\text { performance }\end{array}$} & Pearson Correlation & 1 & $.815^{* *}$ & $.708^{* *}$ & $.679^{* *}$ & $.764^{* *}$ \\
\hline & Sig. (1-tailed) & & .000 & .000 & .000 & .000 \\
\hline & $\mathrm{N}$ & 64 & 64 & 64 & 64 & 64 \\
\hline \multirow[t]{3}{*}{ Market Penetration } & Pearson Correlation & $.815^{* *}$ & 1 & $.486^{* *}$ & $.509^{* *}$ & $.645^{* *}$ \\
\hline & Sig. (1-tailed) & .000 & & .000 & .000 & .000 \\
\hline & $\mathrm{N}$ & 64 & 64 & 64 & 64 & 64 \\
\hline \multirow[t]{3}{*}{ Market Development } & Pearson Correlation & $.708^{* *}$ & $.486^{* *}$ & 1 & $.408^{* *}$ & $.496^{* *}$ \\
\hline & Sig. (1-tailed) & .000 & .000 & & .001 & .000 \\
\hline & $\mathrm{N}$ & 64 & 64 & 64 & 64 & 64 \\
\hline \multirow[t]{3}{*}{ Product Development } & Pearson Correlation & $.679^{* *}$ & $.509^{* *}$ & $.408^{* *}$ & 1 & $.763^{* *}$ \\
\hline & Sig. (1-tailed) & .000 & .000 & .001 & & .000 \\
\hline & $\mathrm{N}$ & 64 & 64 & 64 & 64 & 64 \\
\hline \multirow[t]{3}{*}{ Diversification } & Pearson Correlation & $.764^{* *}$ & $.645^{* *}$ & $.496^{* *}$ & $.763^{* *}$ & 1 \\
\hline & Sig. (1-tailed) & .000 & .000 & .000 & .000 & \\
\hline & $\mathrm{N}$ & 64 & 64 & 64 & 64 & 64 \\
\hline
\end{tabular}

**. Correlation is significant at the 0.05 level (1-tailed).

Results presented on Table 4.7 indicate that there is a positive significant relationship between market penetration and organizational performance $(\mathrm{r}=0.815, p<0.05)$. Thus, the data supports hypothesis $\mathrm{HA}_{1}$ which states that market penetration has a positive effect on organizational performance. The findings concur with Allen and Helms (2016) who stated that firms that implement market penetration strategies tend to sell more of their existing products thus perform better than firms that don't.

There is a positive significant relationship between market development and organizational performance $(\mathrm{r}=$ $0.708, p<0.05)$. Thus, the data supports hypothesis $\mathrm{HA}_{2}$ which states that market development has a positive effect on organizational performance. The findings are in agreement with the research done by Spanos and Lioukas (2001) who concluded that market development is directly related to organizational performance and that there existed a positive evidence of the relationship between market development and organizational performance.

There is a positive significant relationship between product development and organizational performance $(\mathrm{r}$ $=0.679, p<0.05)$. Thus, the data supports hypothesis $\mathrm{HA}_{3}$ which states that product development has a positive effect on organizational performance. The findings concur with Johnson, Whittington and Scholes (2009) who stated that the configuration of activities used by firms to acquire new products is an important factor of organizational performance and that developing new products is another strategic option for an organization.

There is a positive significant relationship between diversification and organizational performance $(r=0.764$, 
$p<0.05$ ). Thus, the data supports hypothesis $\mathrm{HA}_{4}$ which states that diversification has a positive effect on organizational performance. The findings are consistent with those of Christensen and Montgomery (2011) who stated that diversification is a product-market growth strategy in which a new product is developed to serve a completely new market or the same existing market in an effort to beat competition as well as serve the customers better, resulting in improved firm performance.

The study also sought to establish the joint effect of growth strategies dimensions on organizational performance. It was hypothesized (HA5) that market penetration, market development, product development and diversification jointly had a positive effect on organizational performance. The hypothesis was tested using multiple regression.

4.8 Effect of Growth Strategies on the performance of food manufacturing firms in Nairobi County, Kenya

\begin{tabular}{lllllll}
\hline Model Summary & \multicolumn{5}{l}{} \\
\hline Model & R & R Square & Adjusted R Square & Std. Error of the Estimate \\
\hline 1 & $.925^{\text {a }}$ & .856 & .846 & & .82277 & \\
\hline ANOVA & & & & & \\
\hline Model & & Sum of Squares & Df & Mean Square & F & Sig. \\
\hline \multirow{2}{*}{1} & Regression & 237.477 & 4 & 59.369 & 87.701 & $.000^{\mathrm{b}}$ \\
& Residual & 39.940 & 59 & .677 & & \\
& Total & 277.417 & 63 & & & \\
\hline
\end{tabular}

\begin{tabular}{|c|c|c|c|c|c|c|}
\hline \multicolumn{7}{|c|}{ Coefficients } \\
\hline \multirow{3}{*}{\multicolumn{2}{|c|}{ Model }} & \multirow{2}{*}{\multicolumn{2}{|c|}{$\begin{array}{l}\text { Unstandardized } \\
\text { Coefficients }\end{array}$}} & \multirow{3}{*}{$\begin{array}{l}\text { Standardized } \\
\text { Coefficients } \\
\text { Beta }\end{array}$} & \multirow[t]{3}{*}{$\mathrm{T}$} & \multirow[t]{3}{*}{ Sig. } \\
\hline & & & & & & \\
\hline & & $\mathrm{B}$ & Std. Error & & & \\
\hline & (Constant) & .877 & .485 & & 1.809 & .006 \\
\hline & Market Penetration & .745 & .110 & .453 & 6.790 & .000 \\
\hline \multirow[t]{3}{*}{1} & Market Development & .704 & .126 & .329 & 5.589 & .000 \\
\hline & Product Development & .384 & .156 & .188 & 2.457 & .017 \\
\hline & Diversification & .316 & .167 & .165 & 1.886 & .005 \\
\hline
\end{tabular}

a. Predictors: (Constant), market penetration, market development, product development and diversification.

b. Organizational Performance (Dependent Variable)

The results in Table 4.8 indicate that the value of $\mathrm{R}$ squared was 0.856 . This shows that there was variation of 85.6 percent on performance of food manufacturing firms due to changes in market penetration, market development, product development and diversification.

The ANOVA shows the results of the effect of the dimensions of growth strategies on organizational performance. ANOVA results show that the model was positive and significant $(\mathrm{F}=87.701, p<0.05)$. The calculated value $\mathrm{F}=87.70$, showed that market penetration, market development, product development and diversification strategy all positively affect the performance of food manufacturing firms. The significance value $\mathrm{p}<0.05$ indicated that the model was significant. Hence, the results support hypothesis HA5 which states that market penetration, market development, product development and diversification jointly have a positive effect on organizational performance.

The standardized coefficients show that the effect of market penetration on organizational performance was positive and significant $(\beta=0.453, \mathrm{t}=6.790, p<0.05)$, the effect of market development on organizational performance was positive and significant $(\beta=0.329, \mathrm{t}=5.589, p<0.05)$, the effect of product development on organizational performance was positive and significant $(\beta=0.188, \mathrm{t}=2.457, p>0.05)$ and the effect of diversification on organizational performance was positive and significant $(\beta=0.165, \mathrm{t}=1.886, p>0.05)$. This shows that market penetration has the greatest effect on organizational performance and is significant $(\beta=0.453$; $p<0.05$ ).

The full regression model on Table 4.8 depicts that all the dimensions of growth strategies have positive and significant effect on organizational performance. From the unstandardized coefficient, the following regression model was developed; $\mathrm{Y}=0.877+0.745 \mathrm{X}_{1}+0.704 \mathrm{X}_{2}+0.384 \mathrm{X}_{3}+0.316 \mathrm{X}_{4}+\varepsilon$

The unstandardized coefficients show that holding market penetration, market development, product development strategies and diversification strategy to a constant, strategy performance of food manufacturing firms would be at 0.877 , a unit increase in market penetration strategies would lead to an increase in performance of food manufacturing firms by a factor of 0.745 , a unit increase in market development strategies would lead to an increase in performance of food manufacturing firms by factors of 0.704 , a unit increase in product development strategies would lead to an increase in performance of food manufacturing firms by a factor of 0.384 and a unit increase in diversification strategy would lead to an increase in performance of food manufacturing firms by a factors of 0.316 . In this regard therefore, we accept hypothesis HA5 which states that market 
penetration, market development, product development and diversification jointly have a positive effect on organizational performance.

The findings are in support of the argument by Arkolakis (2008) that market penetration is one of the most important growth strategies employed by a few organizations and has positive effects on a firm's performance. Kotler and Armstrong (2011) in agreement with these findings in their study on principles of marketing stated that in pursuing a strategy based on market development, management is attempting to sell greater volumes of existing products in new markets and this in turn positively affects the performance of organizations. The findings also concur with a study conducted by Aosa (1992) an Empirical Investigation of Aspects of Strategy Formulation and Implementation within Large Private Manufacturing Companies in Kenya which stated that product development strategy is used to keep customers satisfied and to stay ahead of the competition, thus, increase firm's performance. In support of the findings is also a study conducted by Njuguna (2008) on competitive advantage and firm performance, an empirical study of Kenyan small and medium sized enterprises who argued that diversification as a strategy is distinct in that when a firm diversifies, it essentially moves out of its current products and markets into new areas hence an improvement in firm performance .

\section{Conclusion}

The findings reveal a positive relationship between the dimensions of growth strategies that is, market penetration, market development, product development and organizational performance, supporting the hypotheses of the study. Further, the findings show that all the four growth strategies have a positive and significant effect on performance.

The findings of the study lead to the following conclusion: There is a linkage between growth strategies and performance of food manufacturing firms in Nairobi, Kenya; and growth strategies are positively and significantly related to the performance of the firms. The findings confirm that growth strategies are crucial in enhancing organizational performance. Hence, implementation of growth strategies would lead to improved organizational performance.

The finding that growth strategies have a positive and significant effect on organizational performance empirically confirms the arguments of strategic management model. The model suggests that implementation of growth strategies create competitive advantage and superior organizational performance. Thus, this study confirms the prediction of the model by showing that firms that implement growth strategies achieve higher performance.

\section{Recommendations}

This study has implications to management policy and practice. Given that the growth strategies were found to be positively related with organizational performance, this study proposes that food manufacturing firms should continually adopt the growth strategies to improve organizational performance.

The study makes a contribution in demonstrating the relationship between growth strategies and organizational performance. However, the study has some limitations: The study adopted a cross-sectional survey research design in which data was collected once at a single point in time due to constraints of cost and time. Although cross-sectional studies are helpful in getting insights into aspects of the variables, perceptions vary over time and face limitations in determining other causal relationships that may affect the study. Therefore, future research should adopt longitudinal research design in data collection to enhance understanding of the linkages between the variables in the study.

This study was conducted on food manufacturing firms in Nairobi County. Manufacturing firms may differ in terms of levels of adoption of the strategies' technology compared to service firms. Thus, the results cannot be generalized to all firms. The study should be replicated in other industries. Such replication could further determine whether the results of this study can be generalized to other sectors.

\section{References}

Allen, F. \& Helms, B. (2016). The mediating role of competitive strategy in international entrepreneurial orientation. Journal of Business Research, 69(11), 5383-5389.

Ansoff, H. I. (1957). Strategies for diversification. Harvard Business Review, 4, (2), 113-124.

Anyango, R. (2007). Challenges of Strategy Implementation. A Survey of Multinational Manufacturing Companies in Kenya. (Master Thesis), University of Nairobi, Nairobi, (1),37-49.

Aosa, E. (1992) An Empirical Investigation of Aspects of Strategy Formulation and Implementation within Large Private Manufacturing Companies in Kenya. Unpublished PhD Thesis, University of Strathclyde, Glasgow.

Arkolakis, C. (2008). Market penetration costs and the new consumers margin in international trade (No. w14214). National Bureau of Economic Research, (I), 15-32.

Binsardi, A. \& Ekwulugo, F. (2003). International marketing of British education: research on the students' perception and the UK market penetration. Marketing Intelligence \& Planning, 21(5), 318-327.

Christensen, H. K., \& Montgomery, C. A. (2011). Corporate economic performance: Diversification strategy versus market structure. Strategic Management Journal, 2(4), 327-343. 
Day, G. S. (2004). The capabilities of market-driven organizations. The Journal of Marketing, 1(3), 37-52.

Eisenhardt, K. M. \& Schoonhoven, C. B. (2010). Organizational growth: Linking founding team, strategy, environment, and growth among US semiconductor ventures, 1978-1988. Administrative science quarterly,3(4), 504-529.

Government of Kenya (2017). Kenya Economic Survey. Kenya: Government Printer.

Ittner, C. D. \& Larcker, D. F. (2011). Quality strategy, strategic control systems, and organizational performance. Accounting, Organizations and Society, 22(3), 293-314.

Johnson G., Whittington, R. and Scholes, K. (2009), Exploring Corporate strategy with MystrategyLab, Financial Times/Prentice Hall, (1), 63-89.

Kenya Association of Manufacturers (2017). Kenya Association of Manufacturers Directory 2017. Nairobi: KAM

Kotler, P., \& Armstrong, G. (2011). Principles of Marketing. Englewood Cliffs, N.J: Prentice Hall 14(1), $188-494$.

Lebans, M., Euske, K. (2006), “A conceptual and operational delineation of performance”. 6(2), 285-300.

Lee, R., \& Grewal, R. (2004). Strategic Response to New Technologies and their Impact on Firm's Performance. Journal of Marketing, 68(4), 157-171.

Miller, D. (1987). The structural and environmental correlates of business strategy. Strategic management journal, $8(1), 55-76$.

Nath, P., Nachiappan, S., \& Ramanathan, R. (2010). The impact of marketing capability, operations capability and diversification strategy on performance: A resource-based view. Industrial Marketing Management, 39(2), 317-329.

Njuguna, J. I. (2008). Competitive advantage and firm performance: An empirical study of Kenyan Small and Medium Sized Enterprises. Unpublished, PhD Thesis, JKUAT.

Odiwor, E. (2014). Growth strategies adopted by top fast-growing medium size companies in Kenya. Unpublished MBA project, University of Nairobi.

Oso, W. K., \&Onen, D. (2011): A General guide to writing research proposals and report. (2 ${ }^{\text {nd }}$ ed.). Kampala: Makerere University, (1),16-22.

Pearce11, J.A., Robinson Jr., RB and Mital A (2008). Strategic Management; Formulation, Implementation and Control, 1oth Ed., Tata McGraw - Hill, New Delhi, (2), 48-57.

Porter, M. E. (1985). Competitive advantage: creating and sustaining superior performance. New York: Free Press.

Rono, J. (2015). Effect of growth strategies on the competitiveness of firms in Kenyan cement industry, 2(2), 3239.

Rumelt, R. P. (1982). Diversification strategy and profitability. Strategic Management Journal, 3(4), 359-369.

Spanos, Y. E., \& Lioukas, S. (2001). An examination into the causal logic of rent generation: contrasting Porter's competitive strategy framework and the resource-based perspective. Strategic management journal, 22(10), 907-934 